Original Research Paper

\title{
Contrasting Effects of Metal Contaminations and Soil Liming on Cations Exchange Capacity and Global DNA Methylation in Betula papyrifera Populations from a Mining Region
}

\author{
${ }^{1}$ Gabriel Theriault and ${ }^{1,2}$ Kabwe Nkongolo \\ ${ }^{1}$ Biomolecular Sciences Program, Laurentian University, Sudbury, Ontario, P3E 2C6, Canada \\ ${ }^{2}$ Department of Biology, Laurentian University, Sudbury, Ontario, P3E 2C6, Canada
}

\author{
Article history \\ Received: 29-08-2015 \\ Revised: $10-12-2015$ \\ Accepted: 26-02-2016 \\ Corresponding Author: \\ Kabwe Nkongolo \\ Biomolecular Sciences \\ Program, Laurentian \\ University, Sudbury, Ontario, \\ P3E 2C6, Canada and \\ Department of Biology, \\ Laurentian University, \\ Sudbury, Ontario, P3E 2C6, \\ Canada \\ Email: knkongolo@laurentian.ca
}

\begin{abstract}
The Greater Sudbury Region in Northern Ontario (Canada) has been one of the most contaminated regions in the world. Soil liming with dolomitic limestone applications has decreased significantly the level of soil acidity resulting in forest regeneration. This reclamation process does not affect the level of soil metal contamination but results in metals availability decrement. The coping mechanisms of birch (Betula papyrifera) to soil metal contamination have been recently characterized. The objective of this study was to assess the effects of soil liming and metal contamination on Cations Exchange Capacity (CEC) and whole DNA methylation in B. papyrifera. Cytosine and adenine methylations were measured using tandem Mass Spectrometry (MS/MS) coupled with LC (LC-MS/MS). The present study confirms that liming increases significantly soil $\mathrm{pH}$ even over 30 years after dolomitic applications. There was a decrease of cations exchange capacity and cytosine methylation in metal-contaminated sites compared to uncontaminated sites. CEC was significantly higher $(\mathrm{p} \leq 0.05)$ in limed and reference distal sites compared to unlimed areas. No significant difference in cytosine methylation level was observed between metal-contaminated limed and unlimed areas. This suggests that metal contamination mostly nickel and copper, the main elements found in higher concentrations in contaminated sites might be associated with cytosine methylation.
\end{abstract}

Keywords: Metal Contamination, Soil Liming, Cytosine Methylation, Cation Exchange, Northern Ontario

\section{Introduction}

The Greater Sudbury Region (GSR) has been one of the most contaminated regions in the world. It has been estimated that $>100 \times 10^{6} \mathrm{t}$ of $\mathrm{SO}_{2}$ and several thousands of tonnes of metals including cobalt $(\mathrm{Co})$, copper $(\mathrm{Cu})$, nickel $(\mathrm{Ni})$ and iron $(\mathrm{Fe})$ were been released by roast pits and smelters located in the GSR (Northern Ontario, Canada). Soils surrounding smelters were completely barren soon after industrialization started with only a few tree species remaining (B. papyrifera was one of the commonest) (Amiro and Courtin, 1981). To reclaim these degraded lands, soil liming and tree planting has been implemented since 1979. This has resulted in improved ecosystem landscapes. Betula papyrifera is a dominant tree species of the boreal forest. It is a pioneer species and rapidly colonizes open areas and it represents over $60 \%$ of tree plant species growing in the GSR. It has been reported that Betula papyrifera is sensitive to changes in soil acidity and soil metal contamination (McCall et al., 1995; Theriault et al., 2013; 2014; Mehes-Smith and Nkongolo, 2015).

Little is known about adaptation of $B$. papyrifera to soil metal contamination even though it plays such a key role in forest sustainability. Soil liming with dolomitic limestone applications has decreased the level of soil acidity resulting in an improvement of plant population health. This reclamation process does not change the level of metal contamination but affects the availability of some metals (Nkongolo et al., 2013; Goupil et al., 2015; Tran et al., 2015). Its effects on Cations Exchange Capacity (CEC) and the overall soil fertility is not clearly established. 
On the other hand, the ecological adaptation process of plants to stressed environments can be associated with cytosine modifications that are environmentally-induced. This non-heritable methylations could influence preferential survival (Flores et al., 2013). Only limited studies on DNA modifications have been conducted under environmental conditions that plants experience in real ecosystems outside artificial laboratory.

The main objective of this study was to assess the effects of soil liming and metal contamination on CEC and whole DNA methylation.

\section{Materials and Methods}

\section{Metal and Cation Exchange Capacity}

Soil, root and leaf samples were collected from nine locations throughout the GSR as described in Theriault et al. $(2013 ; 2014)$. The sampling sites include three pairs of limed and unlimed areas close to smelters and contaminated with metals (Fig. 1). Three distal sites were used as reference. The samples were flash frozen in liquid nitrogen and kept in aluminum papers at $-80^{\circ} \mathrm{C}$ for total cellular DNA extraction. Seeds were collected from a Laurentian research site, in Northern Ontario and stored at $4^{\circ} \mathrm{C}$ prior to germination.

Soil $\mathrm{pH}$ was measured in de-ionized water and in a neutral salt solution $\mathrm{pH}\left(0.1 \mathrm{M} \mathrm{CaCl}_{2}\right)$ (Carter, 2007). The exchangeable cations $\left(\mathrm{Al}^{3+}, \mathrm{Ca}^{2+}, \mathrm{Fe}^{3+}, \mathrm{K}^{+}, \mathrm{Mg}^{2+}\right.$, $\mathrm{Mn}^{2+}$ and $\mathrm{Na}^{+}$) were quantified by ICP-MS analysis of ammonium acetate $(\mathrm{pH} \mathrm{7)}$ extracts of soil samples, with the total exchange capacity being estimated by summation of the exchangeable cations (Hendershot et al., 2008). Metal analysis was performed as described by Abedin et al. (2012) and Nkongolo et al. (2013). Total concentration of metals was measured after digestion of $0.5 \mathrm{~g}$ of soil samples with $10 \mathrm{~mL}$ of $10: 1$ ratio of $\mathrm{HF} / \mathrm{HCl}$ at $150^{\circ} \mathrm{C}$. Total metals were detected using Inductively Coupled Plasma Mass Spectrometry (ICP-MS).

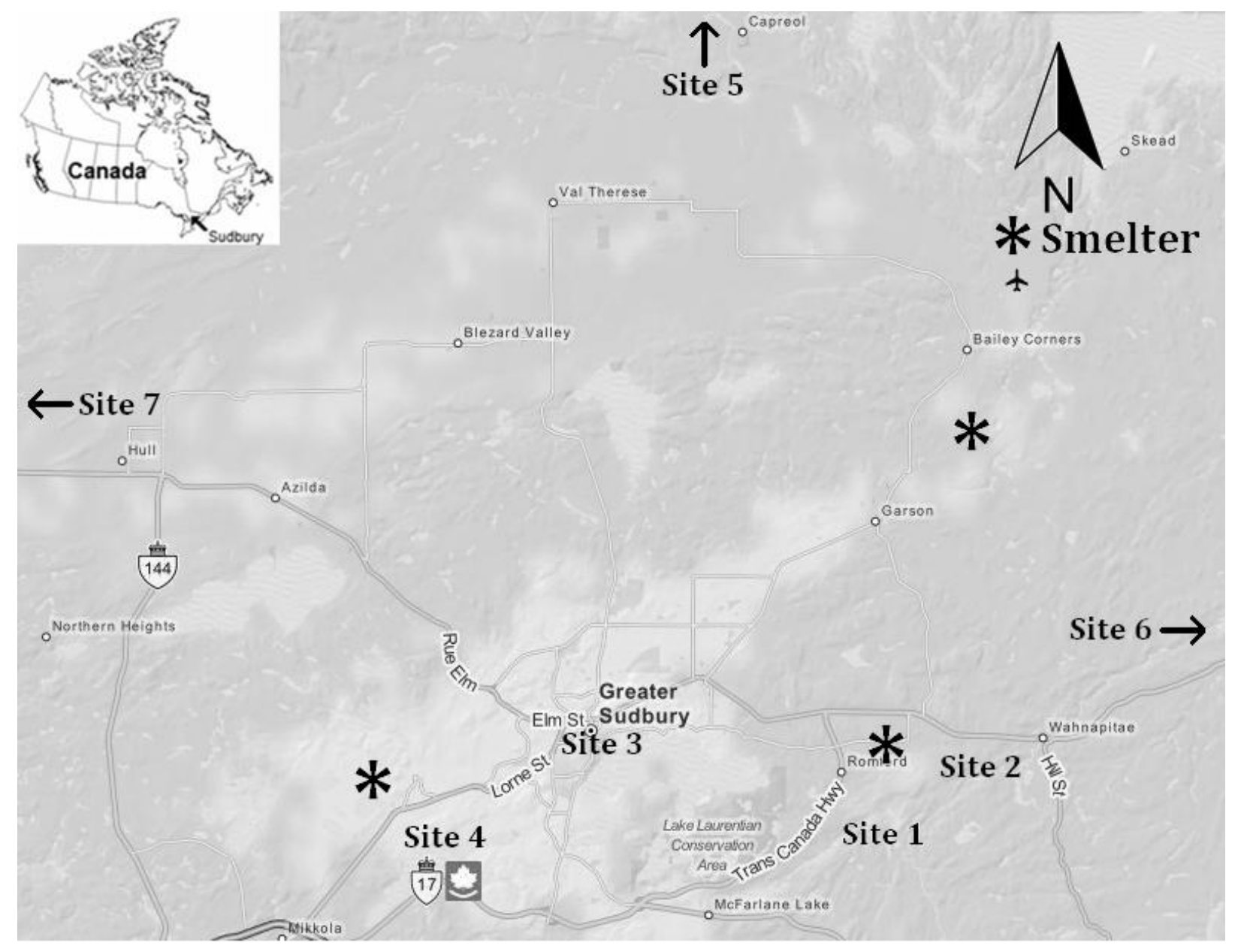

Fig. 1. Locations of white birch sampling sites within the Sudbury region. Site 1: Daisy Lake; Site 2: Wahnapitae Hydro Dam; Site 3: Kingsway; Site 4: Kelly Lake; Site 5: Capreol (control); Site 6: St. Charles (control); Site 7: Onaping Falls (control) 


\section{Whole DNA Methylation}

The total cellular DNA from fresh leaves and roots was extracted using the CTAB extraction procedure described by Mehes et al. (2007) and Nkongolo (1999). After extraction, this genomic DNA was stored in a freezer at $-20^{\circ} \mathrm{C}$.

The general protocol for whole cytosine methylation is described in Tsuji et al. (2014). Nucleoside quantification was determined using Tandem Mass Spectrometry (MS/MS) coupled with LC (LC-MS/MS). Total cellular DNA was digested with DNA Degradase Plus (ZYMO RESEARCH) following the procedure described by the manufacturer. LC separation was performed on a $\mathrm{dC} 182.1 \times 100 \mathrm{~mm}$ column at flow rate of $0.2 \mathrm{~mL} / \mathrm{min}$. The mobile phase was $15 \% \mathrm{CH} 3 \mathrm{OH}$, $85 \% \mathrm{H} 2 \mathrm{O}$ with $1 \%$ formic acid and $10 \mathrm{mM}$ ammonium formate. The injection volume was $15 \mathrm{uL}$. A Waters/Micromass Quattro Micro mass spectrometer was used for the detection of nucleosides. Electrospray ionization in positive ion mode was used to generate ions. Cytosine and adenine methylation levels are reported as $[5 \mathrm{mdC}] /[\mathrm{dG}]$ and $[6 \mathrm{~N}-\mathrm{mdA}] / \mathrm{dT}]$ ratios, respectively.

\section{Statistical Analysis}

All statistical analyses were performed using SPSS version 20 software (SPSS, Chicago, IL, USA). Data were transformed using $\log _{10}$ transformation to achieve a normal distribution. Analysis of Variance (ANOVA) was performed for total metal content, $[5 \mathrm{mdC}] /[\mathrm{dG}]$ and $[6 \mathrm{~N}-\mathrm{mdA}] / \mathrm{dT}]$ values. This was followed by Tukey's
HSD multiple comparison analysis to determine significant differences $(\mathrm{p} \leq 0.05)$ from metalcontaminated among means. Data from analysis of samples frommetal-contaminated and uncontaminated sites and from limed and unlimed areas were compared using Student-T test $(\mathrm{p} \leq 0.05)$.

\section{Results and Discussion}

\section{Cation Exchanges, $p H$ and Soil Metal Contamination}

The present study shows that the $\mathrm{pH}$ values of samples from areas limed with dolomitic stones $>30$ years ago were significantly higher $(\mathrm{p}<0.05)$ compared to those of unlimed samples. But the acidity level between metal-contaminated and uncontaminated site were statistically similar (Fig. 2). Likewise, the level of cation exchange capacity was significantly higher in limed sites compared to unlimed areas. On the other hand, reference sites show a high level of $\mathrm{Ca}^{2+}, \mathrm{Fe}^{2+}$ and $\mathrm{Mg}^{2+}$ cation exchange capacity compared to uncontaminated sites. Significant differences were observed for CEC values between metal-contaminated and distal reference sites. CEC values were also higher in limed areas compared to unlimed sites (Fig. 3). Metal contamination levels are described in Table 1. No significant different was observed for soil metal content levels between limed and unlimed sites. The concentrations of cobalt $(\mathrm{Co})$, copper $(\mathrm{Cu})$ and nickel (Ni) in soil were higher in limed and unlimed areas compared to distal reference sites.

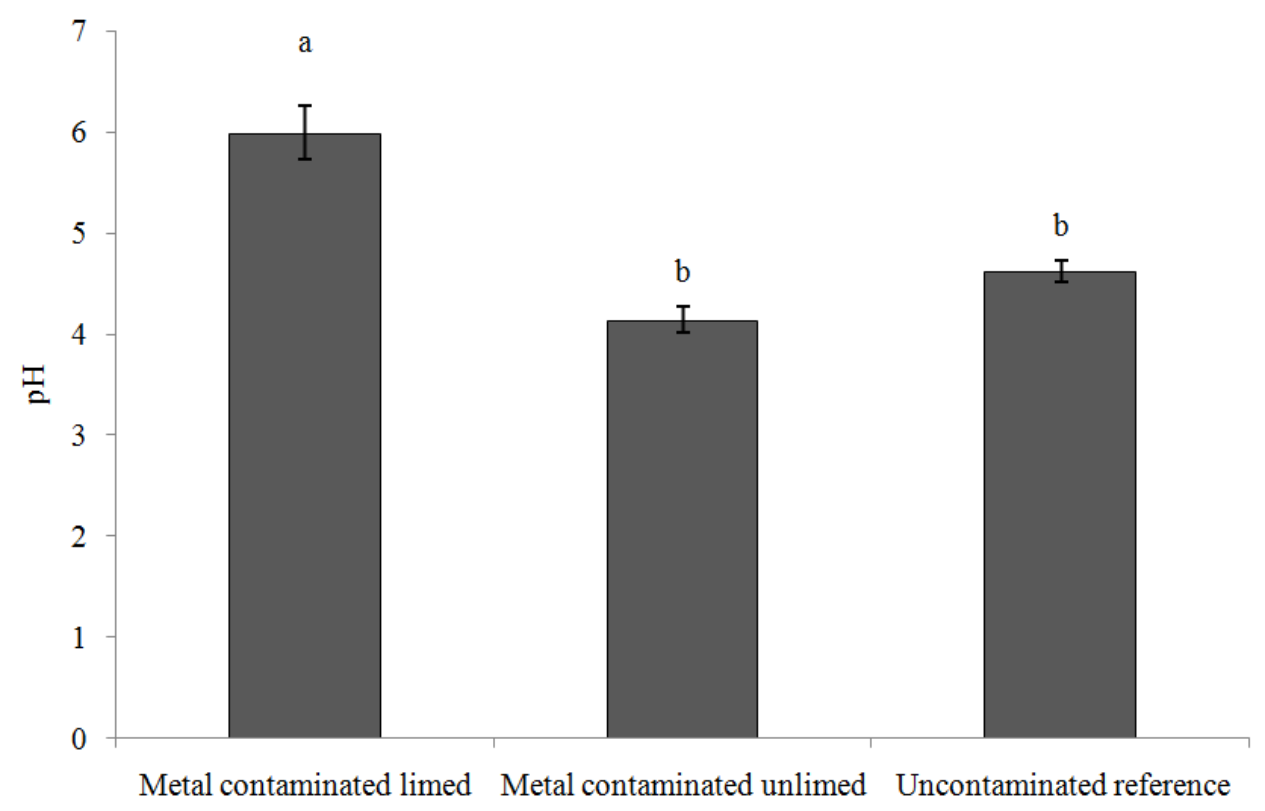

Fig. 2. Soil pH in metal-contaminated limed, metal-contaminated unlimed and metal-uncontaminated reference sites in the Greater Sudbury Region. Means with a common subscript are not significantly different based on Tukey multiple comparison test $(p \geq 0.05)$. Error bars represent standard error 


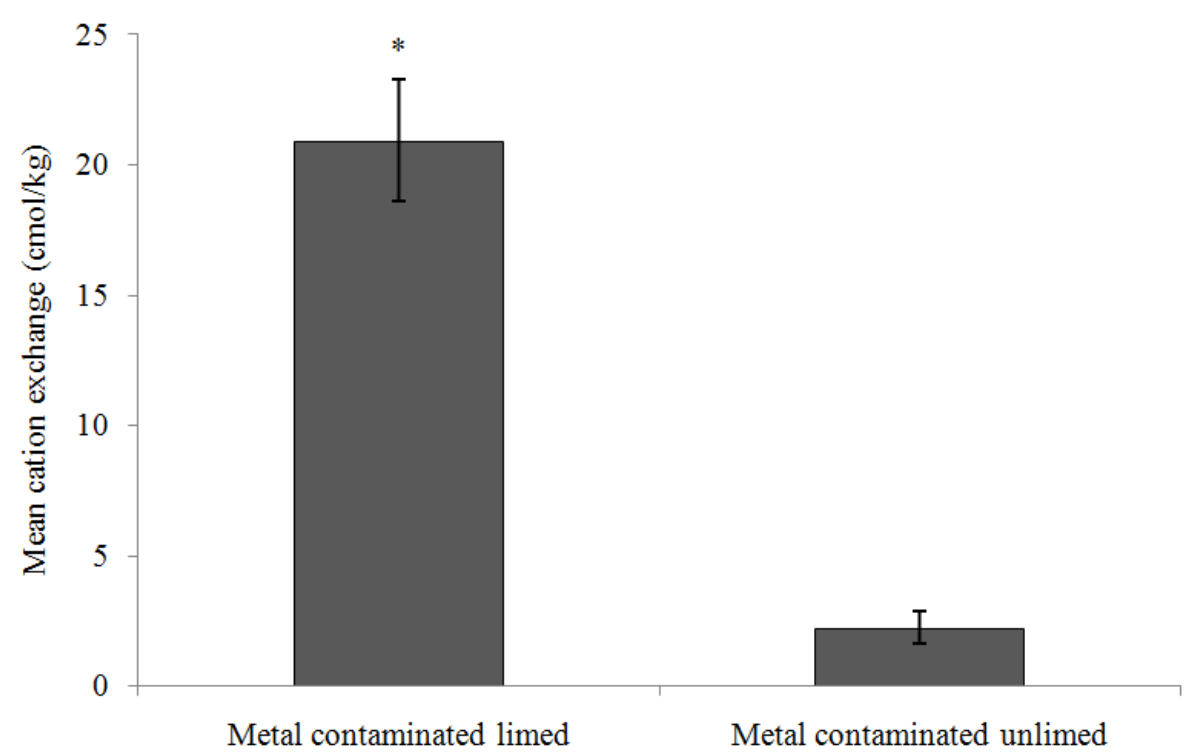

(a)

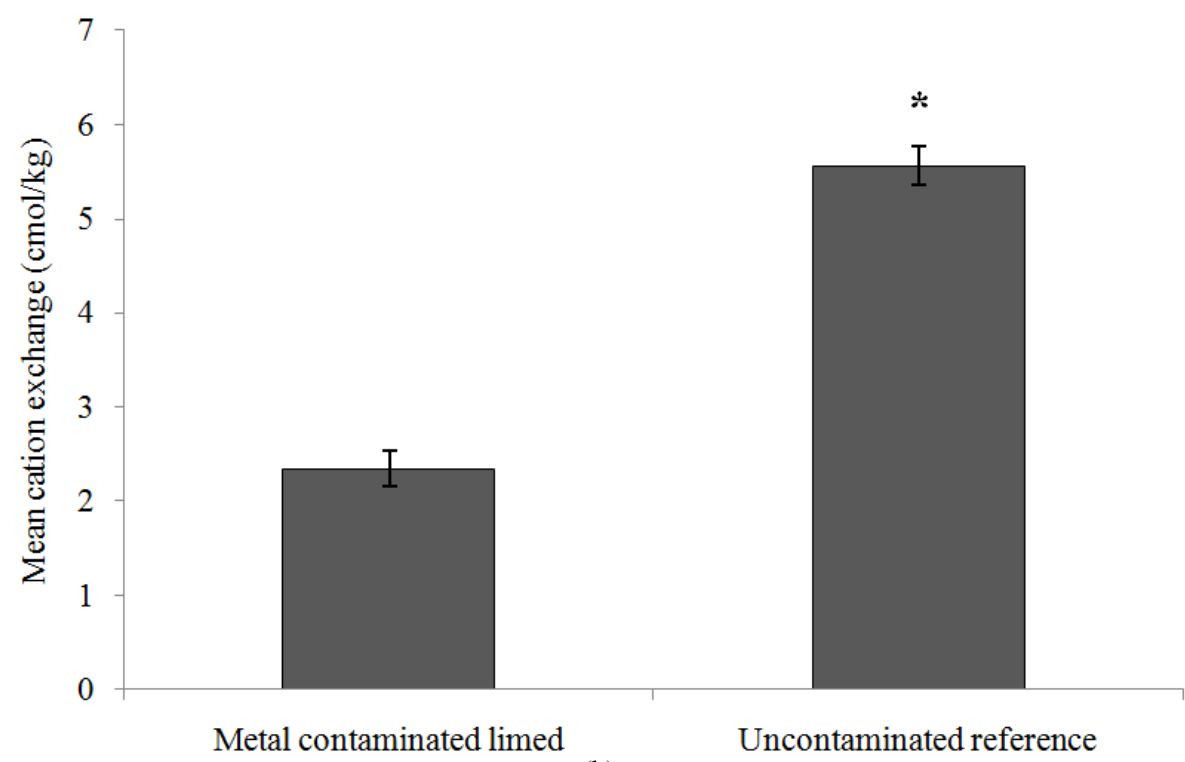

(b)

Fig. 3. Mean cation exchange capacity based seven metals (Al, Fe, Ca, Mg, K, Mn and Na) for (a) Metal-contaminated limed and Metal-contaminated unlimed sites (b) Metal-contaminated and uncontaminated reference sites in the Greater Sudbury Region *indicates significant differences $(\mathrm{p} \leq 0.05)$ between mean data for the two groups of sites

Table 1. Total concentration of nutrients and metals elements in the limed, unlimed and control organic surface horizons (LFH) of soils from the Sudbury region sites (concentrations are in $\mathrm{mg} \mathrm{kg}^{-1}$, dry weight)

\begin{tabular}{llllllllll}
\hline Sites & $\mathrm{As}$ & $\mathrm{Ca}$ & $\mathrm{Co}$ & $\mathrm{Cu}$ & $\mathrm{Pb}$ & $\mathrm{Mg}$ & $\mathrm{Ni}$ & $\mathrm{Sr}$ & $\mathrm{Zn}$ \\
\hline Limed & $31.9^{\mathrm{a}} \pm 59$ & $14526^{\mathrm{a}} \pm 5153$ & $60.2^{\mathrm{a}} \pm 22$ & $1304^{\mathrm{a}} \pm 491$ & $135^{\mathrm{a}} \pm 61$ & $3276^{\mathrm{a}} \pm 213$ & $1552^{\mathrm{a}} \pm 642$ & $75.5^{\mathrm{a}} \pm 3.6$ & $83.1^{\mathrm{a}} \pm 24$ \\
Unlimed & $45.5^{\mathrm{a}} \pm 20$ & $5010^{\mathrm{b}} \pm 298$ & $56.2^{\mathrm{a}} \pm 10$ & $1255^{\mathrm{a}} \pm 359$ & $141^{\mathrm{a}} \pm 44$ & $2176^{\mathrm{b}} \pm 458$ & $1363^{\mathrm{a}} \pm 392$ & $76.5^{\mathrm{a}} \pm 10$ & $76.6^{\mathrm{a}} \pm 18$ \\
Control & $3.46^{\mathrm{a}} \pm 2.2$ & $5880^{\mathrm{b}} \pm 743$ & $10.2^{\mathrm{b}} \pm 3.2$ & $133^{\mathrm{b}} \pm 28$ & $76.2^{\mathrm{a}} \pm 10$ & $1576^{\mathrm{b}} \pm 126$ & $205^{\mathrm{b}} \pm 92$ & $83.5^{\mathrm{a}} \pm 8.4$ & $77.2^{\mathrm{a}^{\mathrm{a}}} \pm 10$ \\
\hline
\end{tabular}

${ }^{*}$ Results are expressed as mean values \pm standard error.

Means in columns with a common subscript are not significantly different based on Tukey multiple comparison test ( $\mathrm{p} \geq 0.05$ ).

This significant improvement of CEC in limed sites appeared to have contributed to an increased soil fertility and improved plant growth. It should be pointed out that the CEC is directly associated with soil $\mathrm{pH}$. Low-pH stress (such as in unlimed areas) resulting to proton toxicity is considered to be one of the main factors 
inhibiting plant growth and development in acid soils (Kochian et al., 2004). It also limits directly plant growth via a high hydrogen ion activity (Schubert et al., 1990; Koyama et al., 2001). A high concentration of protons triggers oxidative stress by inducing an excessive accumulation of Reactive Oxygen Species (ROS) in plant tissues, particularly superoxide radicals and hydrogen peroxide (Shi et al., 2006; Liu et al., 2011). Reactive Oxygen Species (ROS) is the main toxicity mechanism involved in plant stresses including metal contamination. Toxic metalinduced oxidative stress is usually greater in sensitive plants than in tolerant ones such as $B$. papyrifera. In the present study, soil $\mathrm{pH}$ in reference uncontaminated sites was low (similar to metal contaminated unlimed sites) and consistent with the Canadian shields soil acidity. But the CEC values were similar to limed sites with a high $\mathrm{pH}$ suggesting that the association between the two might be overridden by other factors such as organic matter content.

\section{Whole DNA Methylation}

We also consider if epigenetic might be involved in the response of $B$. payrifera to metal contamination and soil acidity and fertility. Analysis of DNA modifications caused by abiotic stresses have shown increase or decrease of hypermethylations, but few studies conducted on the effects of metals in plants reveal that hypomethylation is associated with a high level of metal contamination (Aina et al., 2004). These two phenomena could be involved in the adaptation of plants to stress (Peng and Zhang, 2009).

In the present study, significant differences $(p<0.05)$ for $[5 \mathrm{mdC}] /[\mathrm{dG}]$ was observed between metalcontaminated and uncontaminated sites (Fig. 4a). These differences in methylations can be attributed to either higher $\mathrm{Ni}$ or $\mathrm{Cu}$ contamination or $\mathrm{CEC}$, the two main factors distinguishing the two types of sites. Cytosine methylation levels varied also between roots and leaf samples in some sites (Fig. 4b).

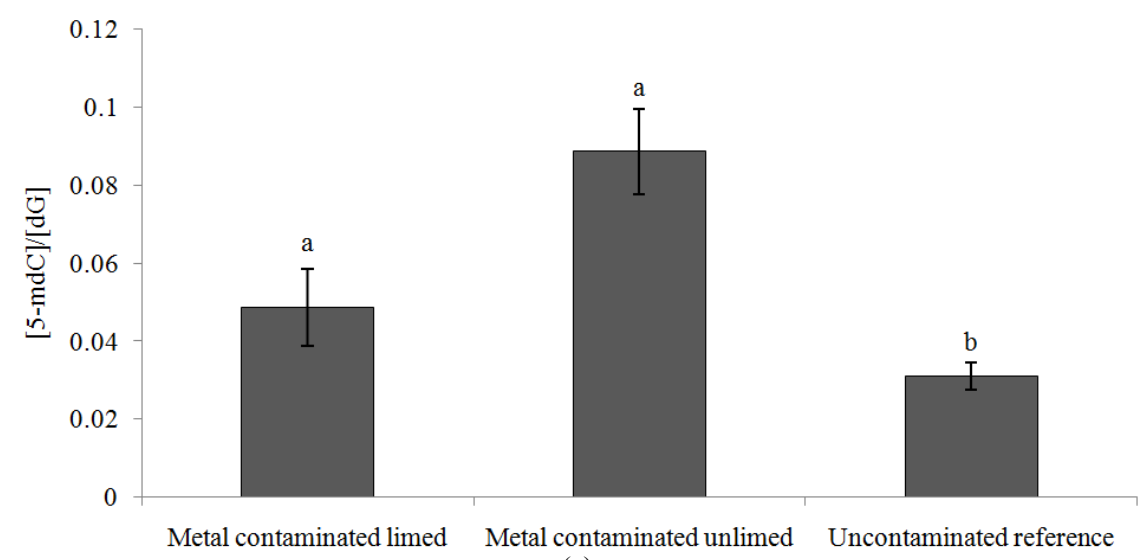

(a)

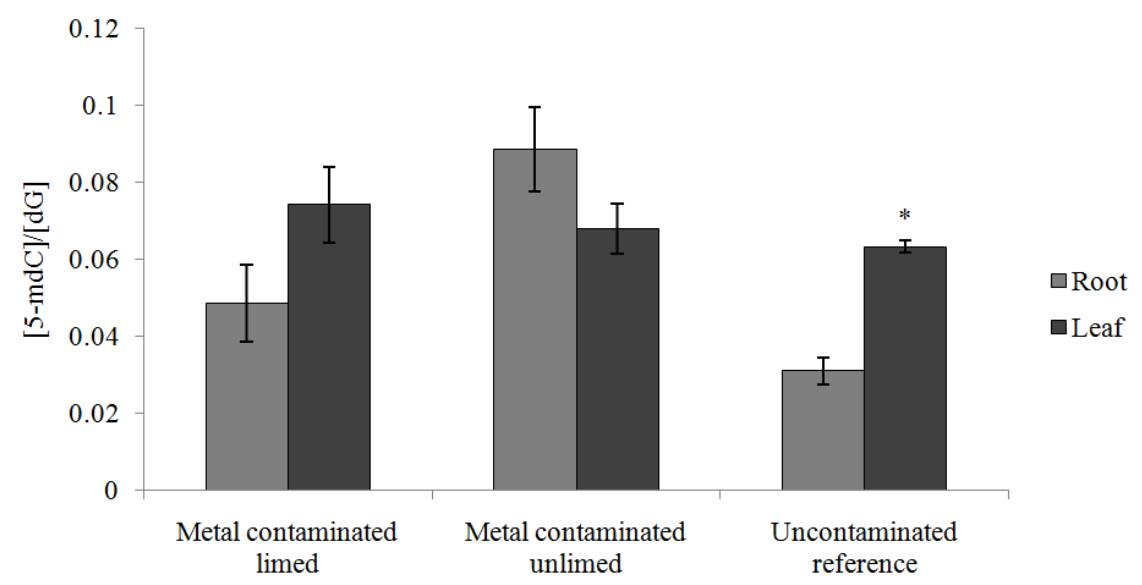

(b)

Fig. 4. (a)Cytosine methylation levels based on ratio of methylated cytosine to guanosine in roots of white birch (Betula papyrifera) populations from limed and unlimed areas. Means with a common subscript are not significantly different based on Tukey multiple comparison test ( $>0.05$ ). (b) Cytosine methylation levels based on ratio of methylated cytosine to guanosine in roots and leaves of white birch populations (Betula papyrifera) from limed and unlimed areas *indicates significant differences $(\mathrm{p} \leq 0.05)$ between root and leaf data 
No significant difference in adenine methylation was observed between limed Vs unlimed sites, metalcontaminated Vs uncontaminated sites and leaves Vs roots. But the analysis of the chromatogram revealed two peaks that were resolved for the N6-mdA, one within the expected range at 5.65 and a second at 4.82 in $30 \%$ of the samples from both contaminated and uncontaminated sites (Fig. 1 -Supplementary materials).

A number of publications have provided convincing evidence that support the role of abiotic stresses including drought and high salinity in DNA methylation (Choi and Sano, 2007; Peng and Zhang, 2009; Chinnusamy and Zhu, 2009; Wang et al., 2010; Kimatu et al., 2011). Reports on the effects of metal contamination, $\mathrm{pH}$, cation exchanges on DNA modifications are limited. The present study suggests that metal contaminations might be involved in DNA methylation.

Tandem Mass Spectrometry (MS/MS) coupled with LC (LC-MS/MS) used in the present study to measure overall levels of DNA methylation is an established approach to nucleoside quantification specifically to measure global cytosine methylation ( $\mathrm{Hu}$ et al., 2013; Tsuji et al., 2014). In particular, it is a fast, sensitive, accurate and specific avenue for modified nucleoside quantification at trace (fmol) levels. Other procedures such as Methylation-Sensitive Amplified Polymorphism (MSAP) and methods based on bisulfite modifications of DNA that analyze the methylation status of specific sequences are also used in many studies. Each of these methods has its own peculiarities. MSAP approach was recently used to assess the effect of metals on cytosine methylation in Acer rubrum (red maple). But this technique was not as sensitive to detect quantitative difference in DNA methylation between metalcontaminated and uncontaminated populations in Acer rubrum populations growing in the GSR (Kalubi et al., 2015). The use of bisulfite sequencing for cytosine methylation would be more informative in mapping the distribution of DNA modifications. But its wide application in plants epigenetic studies is cost prohibitive specifically for species whose genome have not been completely sequenced.

\section{Conclusion}

The present study confirms that nickel and copper are the main contaminants in targeted sites within the GSR and liming increases significantly soil $\mathrm{pH}$ even over 30 years after dolomitic applications. There was a decrease of cations exchange capacity and cytosine methylation in metal-contaminated sites compared to uncontaminated sites. Cations exchange capacity was higher in limed and distal reference sites compared to unlimed sites. No significant difference in cytosine methylation level was observed between limed and unlimed areas with the same levels of metal contamination. This suggests that metal contamination mostly nickel and copper, the main elements found in higher concentrations in contaminated sites might be associated with cytosine methylation.

\section{Future Research Directions, Limitations and Implications}

Control experiments with different dosages of these metals are being conducted to confirm the role of these metals in DNA methylation. In addition bisulfite sequencing will be used to assess the distribution of methylation in the B. papyrifera genome.

\section{Acknowledgment}

We would like to thank the Natural Sciences and Engineering Research Council of Canada (NSERC), Vale and Sudbury Nickel Operations (Glencore Limited) for their financial support. Thanks to Drs. Alexei Gapeev and David Yeh from Millis Scientific, Inc, in Baltimore (USA) for assistance with the LCMS/MS analysis. Thanks to Dr. Graeme Spiers (Elliott Lake Research CLaboratory) for metal and cations exchange analyses.

\section{Author's Contributions}

Gabriel Theriault: Conducted the experiments and analyzed the data.

Kabwe Nkongolo: Coordinated the study and wrote the manuscript.

\section{Ethics}

The authors declare that this is an original research and they have no ethical issues or copyrights conflict.

\section{References}

Abedin, J., P. Beckett and G. Spiers, 2012. An evaluation of extractants for assessment of metal phytoavailability to guide reclamation practices in acidic soilscapes in northern regions. Canad. J. Soil Sci., 92: 253-268. DOI: 10.4141/cjss2010-061

Aina, R., S. Sgorbati, A. Santagostino, M. Labra and A. Ghiani et al., 2004. Specific hypomethylation of DNA is induced by heavy metals in white clover and industrial hemp. Physiol. Plantarum, 121: 472-480. DOI: 10.1111/j.1399-3054.2004.00343.x

Amiro, B.D. and G.M. Courtin, 1981. Patterns of vegetation in the vicinity of an industrially disturbed ecosystem, Sudbury, Ontario. Canad. Can. J. Bot., 59: 1623-1639. DOI: 10.1139/b81-221 
Carter, M.R., 2007. Soil Sampling and Methods of Analysis. 2nd Edn., CRC Press, ISBN-10: 1420005278, pp: 1264.

Chinnusamy, V. and J.K. Zhu, 2009. Epigenetic regulation of stress responses in plants. Curr. Opin. Plant Biol., 12: 133-139. DOI: $10.1016 /$ j.pbi.2008.12.006

Choi, C.S. and H. Sano, 2007. Abiotic-stress induces demethylation and transcriptional activation of a gene encoding a glycerophosphodiesterase-like protein in tobacco plants. Mol. Genet. Genom., 277: 589-600. DOI: 10.1007/s00438-007-0209-1

Goupil, K., K.K. Nkongolo and S. Nasserulla, 2015. Characterization of fungal communities in limed and unlimed lands contaminated with metals: Phospholipid Fatty Acid (PLFA) analysis and soil respiration. Am. J. Biochem. Biotechnol., 11: 45-56. DOI: 10.3844 /ajbbsp.2015.45.56

Flores, K.B., F. Wolschin and G.V. Amdam, 2013. The role of methylation of DNA in environmental adaptation. Integrative Comparative Biol., 53: 359-372. DOI: $10.1093 /$ icb/ict019

Hendershot, W.H., H. Lalande and M. Duquette, 2008. Ion Exchange and Exchangeable Cations. In: Soil Sampling and Methods of Analysis, Carter, M.R. and E.G. Gregorich (Eds.), Taylor and Francis, Boca Raton, ISBN-10: 0849335868, pp: 197-206.

Hu, C.W., H. Lee, J.L. Chen, Y.J. Li and M.R. Chao, 2013. Optimization of global DNA methylation measurement by LC-MS/MS and its application in lung cancer patients. Anal. Bioanal. Chem., 405: 8859-8869. DOI: $10.1007 / \mathrm{s} 00216-013-7305-3$

Kalubi, K., M. Mehes-Smith, N.S. Kim and A. Omri, 2015. Characterization of DNA methylation levels and genetic variation in red maple (Acer rubrum) populations from a mining region contaminated with metals in northern Ontario. Proceedings of the Annual Meeting of American Society of Agronomy, Crop Sciences Society of America and Soil Sciences Society of America held in Minneapolis, Nov. 16-19, USA.

Kimatu, J.N., M. Diarso, C. Song, R.S. Agboola and J. Pang et al., 2011. DNA cytosine methylation alterations associated with aluminium toxicity and low $\mathrm{pH}$ in Sorghum bicolor. Afr. J. Agric. Res., 6: 4579-4593.

Kochian, L.V., O.A. Hoekenga and M.A. Pineros, 2004. How do crop plants tolerate acid soils? Mechanisms of aluminum tolerance and phosphorous efficiency. Annu. Rev. Plant Biol., 55: 459-493.

DOI: 10.1146/annurev.arplant.55.031903.141655
Koyama, H., T. Toda and T. Hara, 2001. Brief exposure to low-pH stress causes irreversible damage to the growing root in Arabidopsis thaliana: Pectin-Ca interaction may play an important role in proton rhizotoxicity. J. Exp. Bot., 52: 361-368. DOI: $10.1093 /$ jexbot $/ 52.355 .361$

Liu, T.T., P. Wu, L.H. Wang and Q. Zhou, 2011. Response of soybean seed germination to cadmium and acid rain. Biol. Trace Elem. Res., 144: 1186-1196. DOI: 10.1007/s12011-011-9053-6

McCall, J., J. Gunn, H. Struik, 1995. Photo interpretive study of recovery of damaged lands near the metal smelters of Sudbury, Canada. Water Air Soil Pollut., 85: 847-852. DOI: $10.1007 /$ BF00476935

Mehes, M.S., K.K. Nkongolo and P. Michael, 2007. Genetic analysis of Pinus strobus and Pinus monticola populations from Canada using ISSR and RAPD markers: Development of genome-specific SCAR markers. Plant Syst. Evolut., 267: 47-63. DOI: 10.1007/s00606-007-0534-1

Mehes-Smith, M. and K.K. Nkongolo, 2015. Physiological and cytological responses of Deschampsia cespitosa and populus tremuloides to soil metal contamination. Water Air Soil Pollut., 226: 125-125. DOI: $10.1007 / \mathrm{s} 11270-015-2382-\mathrm{x}$

Nkongolo, K.K., 1999. RAPD and cytological analyses of Picea spp. from different provenances: Genomic relationships among Taxa. Hereditas, 130: 137-144.

DOI: $10.1111 / \mathrm{j} .1601-5223.1999 .00137 . \mathrm{x}$

Nkongolo, K.K., G. Spiers, P. Beckett, R. Narendrula and G. Theriault et al., 2013. Long-term effects of liming on soil chemistry in stable and eroded upland areas in a mining region. Water Air Soil Pollut., 224: 1-14. DOI: 10.1007/s11270-013-1618-x

Peng, H. and J. Zhang, 2009. Plant genomic DNA methylation in response to stresses: Potential applications and challenges in plant breeding. Prog. Nat. Sci., 19: 1037-1045.

DOI: $10.1016 /$ j.pnsc.2008.10.014

Schubert, S., E. Schubert and K. Mengel, 1990. Effect of low $\mathrm{pH}$ of the root medium on proton release, growth and nutrient uptake of field beans (Vicia faba). Plant Soil, 124: 239-244.

DOI: $10.1007 / \mathrm{BF} 00009266$

Shi, Q.H., Z.J. Zhu, J. Li and Q.Q. Qian, 2006. Combined effects of excess $\mathrm{Mn}$ and low $\mathrm{pH}$ on oxidative stress and antioxidant enzymes in cucumber roots. Agric. Sci. China, 5: 767-772. DOI: 10.1016/S1671-2927(06)60122-3 
Theriault, G., K.K. Nkongolo, R. Narendrula and P. Beckett, 2013. Molecular and ecological characterisation of plant populations from limed and metal-contaminated sites in Northern Ontario (Canada): ISSR analysis of white birch (Betula papyrifera) populations. Chem. Ecol., 29: 1-13. DOI: $10.1080 / 02757540.2013 .820715$

Theriault, G., K.K. Nkongolo and P. Michael, 2014. Genetic and metal analyses of fragmented populations of Betula papyrifera (Marsh) in a mining reclaimed region: Identification of population-diagnostic molecular marker. Ecol. Evolut., 4: 3435-3443. DOI: 10.1002/ece3.1195

Tran, T., K.K. Nkongolo, M. Mehes-Smith, R. Narendrula and G. Spiers et al., 2015. Heavy metal analysis in red oak (Quercus rubra) populations from a mining region in Northern Ontario (Canada): Effect of soil liming and analysis of genetic variation. Am. J. Environ. Sci., 10: 363-373.

DOI: 10.3844/ajessp.2014.363.373
Tsuji, M., H. Matsunaga, D. Jinno, H. Tsukamoto and N. Suzuki et al., 2014. A validated quantitative liquid chromatography-tandem quadrupole mass spectrometry method for monitoring isotopologues to evaluate global modified cytosine ratios in genomic DNA. J. Chromatogr. B, 953-954: 38-47.

DOI: $10.1016 /$ j.jchromb.2014.01.050

Wang, W.S., P.J. Pan, X.Q. Zhao, D. Dwivedi and L.H. Zhu et al., 2011 Drought-induced sitespecific DNA methylation and its association with drought tolerance in rice (Oryza sativa L.). J. Exp. Botany, 62: 1951-1960. DOI: 10.1093/jxb/erq391

\section{Supplementary Materials}

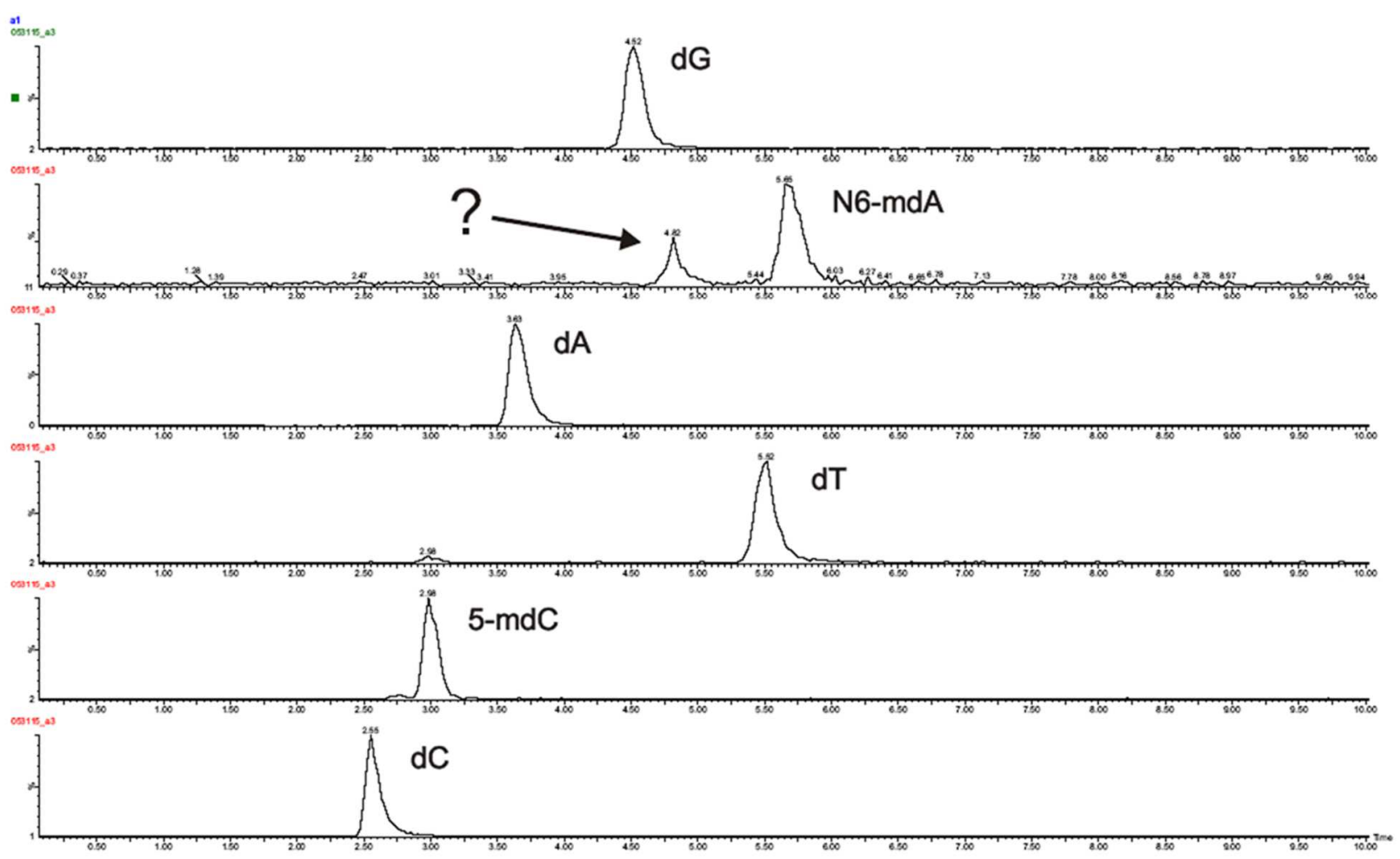

Fig. 1. Integrated LC-MS/MS chromatograms for dG, N6-mdA, dA, dT, 5-mdC, and C. The arrow indicates unusual second peak for N6-mDA in Betula papyrifera DNA samples 